\title{
Ultrafiltration for environment safety in shellfish production: removal of oyster gametes in hatchery effluents
}

\author{
Cordier Clémence ${ }^{1}$, Stavrakakis Christophe ${ }^{2}$, Dupuy Beatrice ${ }^{2}$, Papin Mathias ${ }^{2}$, Sauvade Patrick ${ }^{3}$, \\ Coelho Franz ${ }^{3}$, Moulin Philippe ${ }^{1,}$
}

${ }^{1}$ Laboratoire de Mécanique, Modélisation et Procédés Propres (M2P2-CNRS-UMR 7340), Aix-Marseille Université, Europôle de l'Arbois, BP 80, Bat. Laennec, Hall C, 13545 Aix-en-Provence cedex 04, France ${ }^{2}$ Laboratoire Sécurisation des Productions en Conchyliculture, Station Ifremer de Bouin, Polder des Champs, 85230 Bouin, France

${ }^{3}$ Suez - Aquasource, 20, avenue Didier Daurat, 31029 Toulouse cedex 04, France

* Corresponding author : Philippe Moulin, email address : philippe.moulin@univ-amu.fr

\begin{abstract}
:
Triploid oysters are favoured by the aquaculture industry because of their sterility, which results in two advantages: a faster growth than natural oysters and a constant quality throughout all the year, which is attractive for consumers. In France, these oysters are mainly produced by mating natural and tetraploid oysters whose production poses a risk for marine environmental biodiversity if biological material is released into the environment. Therefore, effluents from farms which could produce those kinds of oysters must be treated. The objective of this work was to treat shellfish hatchery effluents by ultrafiltration. The retention of gametes by the membrane, was validated for different scenario, 5 log removals were obtained, and their viability was evaluated after treatment highlighting a destruction of these species after air-backwash. The sustainability of the process facing this organic pollution on the duration of each test but also on the period of the study was demonstrated. A protection of the marine environment biodiversity is obtained with ultrafiltration processes.
\end{abstract}

\section{Graphical abstract}

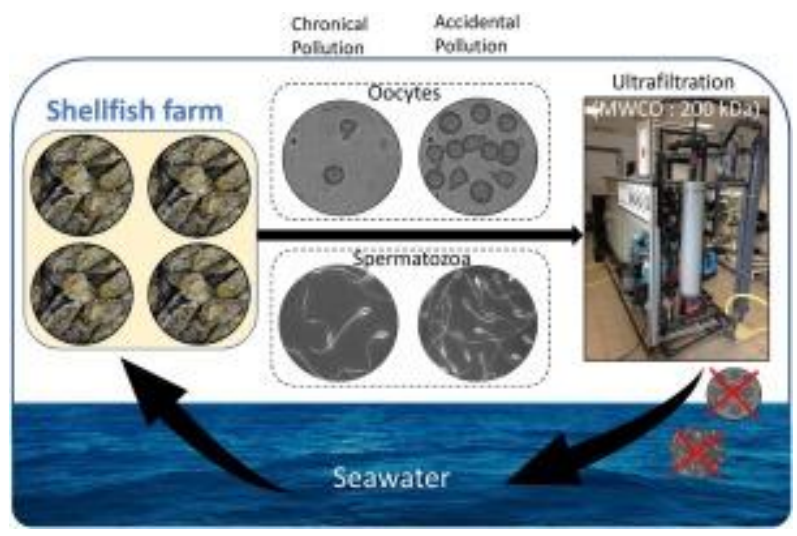




\section{Highlights}

- The retention of gametes from oyster Crassostrea gigas (3-5 log) by ultrafiltration was demonstrated. - The organic fouling generated was controlled by membrane cleanings: sustainability of the process over 7 months. Degradation of the structure of gamete is observed during backwash with air. Chronical and accidental pollutions were treated. A protection of the marine environment is obtained with ultrafiltration.

Keywords : Ultrafiltration, hatchery effluents, oyster gametes removal, marine biodiversity 


\section{Introduction}

In aquaculture, the management of incoming water and effluents requires the use of seawater treatment and disinfection processes, especially in a context of the increasing sanitary crises 
affecting livestock. In particular, shellfish farming faces two challenges: upstream degradation of the quality of coastal water, in particular the presence of pathogens responsible for high mortality in juveniles and adults, but also the preservation of the environment and biodiversity through the production of specific, or exotic oysters, in commercial hatcheries. The biosecurity of farms is therefore a priority for many professionals who have to deal with new environmental regulations. In this context, the development of reliable methods with which an entire removal of that specific biological material must be studied. This is the case of the production of triploid oysters, which, unlike natural diploid oysters, have a faster growth and a constant taste quality throughout the year, since they do not enter gametogenesis (Guo et al., 1996). One of the techniques used to produce them is to cross tetraploid oysters with diploid oysters (Benabdelmouna and Ledu, 2008). It is the production of these tetraploid shells that impose a risk for marine biodiversity. Indeed, if biological material was released into the environment, the danger could be the sterilization of oysters naturally present in the environment. The elimination of gametes (spermatozoa and oocytes) from the effluents of shellfish farms likely to produce them is therefore essential. Indeed, in the production cycle of a shellfish hatchery, farms are conditioned almost continuously to bring them to sexual maturity and then use them as spawners for spat production. With the aim of answering water quality management issues in aquaculture, numerous studies have been conducted to compare disinfection processes for these effluents. While the principal uses are chemical oxidation and UV radiation, the performances of electrolytic methods, heat, $\mathrm{pH}$, salinity, and temperature have also been studied on various pathogens encountered in aquaculture (Arimoto et al., 1996; Frerichs et al., 2000; Kasai et al., 2011, 2002; Liltved et al., 1995; Sharrer et al., 2005; Summerfelt, 2003; Torgersen and Hastein, 1995).

Membrane processes are used to treat water supply (Szmukala and Szaniawska, 2009). Nanofiltration has been effective to remove contaminants such as BOD, total phosphorous and 
total iron to required limits. In seawater, microfiltration is used to eliminate toxic micro algae: a total removal of toxic dinoflagellates from seawater by immersed microfiltration membranes has been realized (Castaing et al., 2011). For the treatment of effluents, membrane processes have been tested in the case of Recirculating Aquaculture Systems (RAS) in fresh or sea water for the retention of fine particles and biomass in effluents. Thus, the performance of microfiltration (Gemende et al., 2008), ultrafiltration (Harvianto, 2013), nanofiltration (Nora'aini et al., 2005) and reverse osmosis (Qin et al., 2005) were evaluated in terms of both retention and production.. In searching for a way to overcome fouling, Chen et al. (2015) evaluated the feasibility of membrane filtration coupled with catalytic ozonation while Yang et al. (2006) performed a combination of membrane filtration and chemical precipitation. An enhancement of permeate flow was observed in both studies. A two-stage filtration using ceramic membranes with different cut-offs (1.0 and $0.45 \mathrm{kDa})$ can be used in one of the stages of effluent water (Bonisławska et al., 2016). Several studies have also demonstrated the benefit of integrating membrane bioreactors for the control of water quality in a RAS. In fact, it has been shown that the system is improved in fresh water without (Pulefou et al., 2008) or with salt (Sharrer and Summerfelt, 2007; Wold et al., 2014) by reducing turbidity and by lowering the total number of bacteria in the backwash. In the Membrane Bio Reactor (MBR), the frequency of cleaning could be halved (Jegatheesan et al., 2009).

In the particular case of shellfish hatcheries, few studies exist to evaluate the treatment performance of removing biological material from the effluent. For this application, Ifremer nevertheless validated various seawater disinfection processes. The effectiveness of oxidation by chlorine and ozone and UV radiation, the most widely used processes for the disinfection of seawater, have been studied for the inactivation of biological material of oysters Crassostrea gigas (Stavrakakis et al., 2017). The impact of chlorine on oyster larvae has also been put forward on the effect of enzymatic passage on embryonic development of Pacific oysters, 
(Bamber et al., 1994) and chlorination was considered as a potential spermicide for different marine invertebrates (Muchmore and Epel, 1973). Although the effectiveness of chemical disinfection by chlorine or ozone has been demonstrated, this technique has the disadvantage of potentially generating additional pollution by the creation of disinfection by-products (Delacroix et al., 2013; Kornmueller, 2007; Lazarova et al., 1999). Indeed, the oxidizing species react by creating reactive subspecies potentially harmful for the aquatic environment (Reiser $e t$ al., 2011). Bromoform (Heeb et al., 2014) is one of the disinfection by-products identified by the International Maritime Organization (IMO) as potentially dangerous for the environment and for humans exposed to it (IMO, 2009). UV radiation is therefore considered to be an effective alternative to ozonation and chlorination for the inactivation of pathogens in aquaculture farms (Brown and Russo, 1979; Cobcroft and Battaglene, 2013) because they generally do not lead to creation of disinfection by-products. According to Ifremer, a dose of 40-80 $\mathrm{mJ} . \mathrm{cm}^{-2}$ delivered by a low-pressure UV system is not totally effective for the treatment of gametes or oyster larvae. (Li et al., 2000) also studied the effects of ultraviolet radiation on oyster sperm Crassostrea gigas, showing that irradiation for $60 \mathrm{~s}$ at an intensity of $72 \mathrm{~mJ} . \mathrm{cm}^{-2}$ was the optimum dose to achieve haploid genesis. However, the effectiveness of removing pathogens by UV is linked to the turbidity of water (Gullian et al., 2012; Qualls and Johnson, 1983). Generally, in water treatment, there is no universal effluent treatment method and in the particular case of shellfish farming, the two proposed processes generate either additional pollution or limited efficiency related to the quality of the effluent. About membrane processes, due to the high concentration of salt (sea water), the high flow rate and the quality of water, MBR, NF and RO can't be used respectively.

The development of reliable and robust processes with respect to a variable pollution both in concentration but also in species leaving shellfish farms is necessary. The objective of this study is to evaluate the efficiency of ultrafiltration for the retention of spermatozoa and oocytes of 
Crassostrea gigas oysters in the case of continuous pollution with low concentrations, or intermittent pollution with high concentrations, as they may occur in farms conditioned for sexual maturation. The viability of these species was studied after treatment by flow cytometry and microscopic analysis.

\section{Materials and Methods}

II.1 Seawater and effluents

The gamete treatment trials were conducted at Ifremer station in Bouin (France) continuously supplied with seawater (Atlantic Ocean) from Bourgneuf Bay. Over the 6 months of tests, the quality of the incoming seawater was characterized by (Min - Max - Average): turbidity (0.674 - 13.4 - 4.5 NFU), salinity (30.8 - 34.7 - 33.5 g.L $\left.\mathrm{L}^{-1}\right)$, chlorophyll a $\left(0.89-7.04-4.5 \mu \mathrm{g} . \mathrm{L}^{-1}\right)$ and pheo-pigments $\left(0.24-1.84-0.71 \mu \mathrm{g} . \mathrm{L}^{-1}\right)$. Measurement of Chlorophyll and pheo-pigments sheds light on the viability of algal cells. After pre-treatment which consists of settling in tailing ponds, filtration with sand filters (suspended solid cut off: $25-30 \mu \mathrm{m}$ ) and UV treatments, only turbidity is measured (value less than $10 \mathrm{NFU}$ ) in the inlet farm. Filtration experiments were performed with 2 types of pollution: (i) chronic pollution corresponding to a continuous release of small quantities of gametes and (ii) accidental pollution corresponding to a short-term rejection of a high quantity of gametes during spontaneous spawning of all the individuals of the same breeding or during fertilization, during which the surplus of gametes can be rejected in the effluents. A spontaneous spawning can occur when a slight difference of temperature is observed in the rearing tanks or after cleaning operations, resulting in an increased expulsion of gametes. These two types of effluents have gamete concentrations reflecting conditions observed in commercial oyster spat production. For chronic pollution, filtration of sperm and oocyte solutions was monitored for more than two days $(30 \mathrm{~h})$ with concentrations around 10000 spz.mL $L^{-1}$ or 69 oo. $\mathrm{mL}^{-1}$. For accidental pollution, the effluents were treated for 5 hours with membrane inlet concentrations around $200000 \mathrm{spz} \cdot \mathrm{mL}^{-1}$ and 300 oo.mL $\mathrm{mL}^{-1}$. In order to 
obtain these concentrations, a highly concentrated solution of spermatozoa or oocytes was prepared and then fed into the buffer tank for feeding the membrane. This concentrated solution was obtained from sexually mature oysters Crassostrea gigas called "broodstock", raised on the Ifremer experimental platform of Bouin (France) in optimal conditions of temperature and food allowing gametogenesis. The sex of the oysters was determined by analysis of a gonad sample by microscopy and the gametes were recovered by scarification of the gonad. Gametes size is around 30- $40 \mu \mathrm{m}$ for oocytes, and $1 \mu \mathrm{m}$ for spermatozoa. With the pore size of the membrane at $0.02 \mu \mathrm{m}$, a retention of these species is then expected with this ultrafiltration process.

\section{II.2 Membrane, pilot plant and operating conditions}

Aquasource hollow fiber membranes were used for all the tests. The Molecular Weight Cut Off (MWCO) of this polyethersulfone UF membrane is $200 \mathrm{kDa}$, the pore size is $0.02 \mu \mathrm{m}$ and the initial permeability is $1000 \mathrm{~L} \cdot \mathrm{h}^{-1} \cdot \mathrm{m}^{-2} \cdot \mathrm{bar}^{-1}$. The relative difference between the pore size and the gametes size has a big impact in reducing the fouling at the membrane surface and mere especially in working with sustainable conditions. Moreover sea water was filtered and it is already highlight the high potential of ultrafiltration, compared to microfiltration (Guilbaud et al., 2015). Each hollow fiber consists of 7 channels of $0.9 \mathrm{~mm}$ of internal diameter, for a total area of the UF module of $8 \mathrm{~m}^{2}$. The membrane module has been integrated into a semi industrial pilot (Moll et al., 2007), and is able to treat $20 \mathrm{~m}^{3} \cdot \mathrm{d}^{-1}$. The installation is completely automated and is able to adapt the filtration parameters to the water quality. The pressurized air was supplied by a compressor. To control the operating performances, pressure and temperature sensors and flowmeters were connected to a data logger, and this was all controlled by an industrial programmable PLC. A feed tank was continuously supplied with pretreated seawater. In the case of chronic pollution, a pump injects a concentrated solution into the feed tank with 
a controlled flow rate that is a function of the production flux in order to keep the gamete concentration at the inlet of the module constant. In the case of accidental pollution, gametes are suddenly injected into the feed tank. Before entering the module, the feed is prefiltered to retain particles larger than 130 microns. The tests were all performed in dead end filtration and the permeate was recovered in a buffer tank in order to be used for membranes backwashing. To eliminate fouling, three different membrane cleanings were automatically performed by the pilot: classical backwashes (CB), air backwashes (AB), which consists in a first step of membrane draining by air injection in the membrane before backwashing, and chemical cleaning (CEB). Prefiltre was backwashed every $\mathrm{CB}$ or $\mathrm{AB}$, using $15 \mathrm{~L}$ of permeate for this operation. Membrane permeability (Lp), temperature and transmembrane pressure (TMP) are recorded continuously every minute. All the results, permeate flux and permeability, are expressed taking into account the variation of viscosity versus temperature. Filtration conditions, permeate flux $\left(\mathrm{L} \cdot \mathrm{h}^{-1} \cdot \mathrm{m}^{-2}\right)$ and filtration time (min), were pre-selected according to the literature (Guilbaud et al., 2018) in order to have a sustainable flux. The sustainable flux is the one at which a modest degree of fouling occurs, providing a compromise between capital expenditure (which is reduced by using high flux) and operating expenses (which are reduced by restricting the fouling rate) (Field and Pearce, 2011).

\section{II.3 Analyses}

Flow cytometry offers a quantitative and qualitative analysis of gametes based on the fluorescence of cells by the addition of a marker called fluorochrome. Cell characteristics such as size and shape are detected by scrolling particles in front of a laser and can be classified as such. The cytogram obtained puts in light populations that appear in area specific to the analysed characteristics of cells. In the case of gametes, methods were developed for this study to highlight, according to the size and shape of the cells analysed, a cytogram area that 
corresponds to oocytes or spermatozoa (Le Goic et al., 2014; Vignier et al., 2017). The gamete samples were analysed by flow cytometry on a Partec Cyflow Space flow cytometer to determine the concentration. Two analyses of $800 \mu \mathrm{L}$ were carried out for each sample in order to verify the reproducibility. A third analyse could be performed if this reproducibility condition was not reached. Oocytes viability was measured using two fluorescence labels: SYBR-Green, which marked live and dead cells and Propidium Iodide (PI) which marked cells with damaged membranes. $10 \mu \mathrm{L}$ of SYB-Green and $5 \mu \mathrm{L}$ of PI were mixed to the $800 \mu \mathrm{L}$ oocytes sample. This solution was then analysed after $10 \mathrm{~min}$ in the dark (Le Goic et al., 2014). Spermatozoa viability was determined using the same method but with SYBR-14 instead of SYBR-Green. Fluorescent labeling, SYBR-Green, SYBR-14 and PI, used for cytometry analyses were purchased from Fisher. In addition to cytometry analyses, oocytes and spermatozoa were observed on a phase contrast microscope connected to a video camera. Spermatozoa were filmed on Malassez counting cells to determine the spermatozoa spleen in the sample (movies were 5 seconds long). Moreover, oocytes were characterized by observing their status (shape) and possible degradation of their structure on pictures.

\section{Results and discussion}

\section{III.1 Seawater filtration}

The seawater filtration of Bourgneuf Bay was carried out over a period of 6 months under different filtration conditions (flow and time between 2 backwashes). The filtration parameters were recorded every minute over the entire test period to monitor the behaviour of the membranes. The fouling was a function of two factors: the operating conditions imposed and the quality of the treated water. The resistance of the membrane was around $510^{11} \mathrm{~m}^{-1}$. Using a series resistance model, the reversible and irreversible resistances are determined after each backwashing under constant permeate flow and time conditions. Reversible and irreversible 
resistance is referred to as the relative fouling resistance that disappears and the resistance that is not removed by backwashing. It is noted, for the quality of treated water, under mild (J60t20) or strong conditions (J80-t45) (Figure 1), that the fouling resistance is always less than or equal to resistance of the membrane. This is explained by the need to operate with sustainable conditions and to choose the ultrafiltration process. The reversible resistance in both cases is low and increases slightly. The irreversible resistance increases after each backwash but decreases very strongly after each backwash with a previous air injection. The fouling is then controlled over time with this procedure justifying this type of backwash. $R_{\text {irr }}$ increases with the flux of permeate imposed with a constant time between two backwashes and vice versa. Indeed, the longer the filtration time, the longer the material will accumulate on the surface of the membrane, increasing the fouling and therefore the fouling resistance. Similarly, the fouling force increases with the filtration volume which results in an increase of the fouling resistance. It should be noted that these values must be moderated by the quality of incoming water during the test, even if each condition had been duplicated two times randomly to take into account the variability of the sea water quality. These filtration tests of pre-treated seawater were intended to determine filtration conditions, in order to perform gamete treatment tests. The filtration flux had to be close to industrial conditions but two limits had to be taken into account: the maximum gamete production allowed in the laboratory and the fouling potential generated by the injection of biological material. Similarly, the filtration time must be long enough in terms of process productivity because (i) the permeate is used for backwashing and (ii) the volume generated during these cleaning procedures corresponds to an effluent that must be treated and must be as low as possible. A flux of $60 \mathrm{~L} \cdot \mathrm{h}^{-1} \cdot \mathrm{m}^{-2}$ and filtration times of $30 \mathrm{~min}$ and $60 \mathrm{~min}$ were thus selected. The permeability monitoring obtained under these conditions is presented in Figure 2. The robustness of the ultrafiltration process must be validated. It appeared that the permeability of the membrane was constant over the 7-month period of study, including the seasonal 
variability of the seawater, the previous seawater filtration experiments, the effluents containing gametes filtration, and the extreme and accidental case of a contaminated seawater supply (Figure 3). This accident results in a drop of the permeability 10 times lower than the initial permeability. After every CEB carried out following these events, a permeability of $700 \mathrm{~L} . \mathrm{h}^{-}$ ${ }^{1} \cdot \mathrm{m}^{-2} \cdot \mathrm{bar}^{-1}$ was found. For this study, a CEB was carried out every 2 or 3 days depending on the conditions of filtration and the quality of the seawater supplied. The robustness of the ultrafiltration process was demonstrated over time.

\section{III.2 Treatment of seawater effluents containing oyster spermatozoa}

The objective in these treatment trials is twofold: (i) the gamete retention by the process must be total for different filtration conditions and gamete concentrations in the effluent, and (ii) the fouling caused by this biological material must be controlled over time.

\section{III.2.1 Chronic pollution}

The aim of the chronic gametes pollution treatment trials is to evaluate the performance of ultrafiltration against an effluent leaving the shellfish hatchery, which is low concentrated in gametes but continues over time. Two filtration conditions were tested: a flux at $60 \mathrm{~L} \cdot \mathrm{h}^{-1} \cdot \mathrm{m}^{-2}$ and two filtration times, 30 and 60 min for a 2-3 days experiment. The filtration performance monitored continuously over the $30 \mathrm{~h}$ of test are presented Figure 4 (a-b) for a filtration time of 60 minutes. In order to determine the fouling caused by the spermatozoa during the tests, these evolutions of permeability were compared to tests with sea water without gametes under the same conditions of filtration (Figure 4b). Whatever the operating conditions, the decrease in permeability is substantially greater in the case of filtration of seawater dopped with spermatozoa but the fouling generated remains moderate. The drop of permeability observed over the $30 \mathrm{~h}$ of test is in fact around $250 \mathrm{~L} \cdot \mathrm{h}^{-1} \cdot \mathrm{m}^{-2} \cdot \mathrm{bar}^{-1}$ for both tests. The impact of filtration time on filtration performance is therefore limited, in the treatment conditions. The variations 
in permeability observed, show the importance of air backwash in the control of membrane fouling. The gain of backwash with a previous air injection in membranes on hydraulic performance is thus highlighted for the treatment of seawater effluent dopped with spermatozoa from oysters. The concentrations at the different points of the system (membrane inlet, backwash, air backwash and permeate) were followed by flow cytometry over the $30 \mathrm{~h}$ of test. The concentrations obtained for the different conditions are presented in Table 1 and an example of evolution of spermatozoa concentration in Figure 5. The cytograms obtained are presented in Tables 2 and 3. The spermatozoa concentration measured at the membrane inlet is in agreement with the expected value, $10,000 \mathrm{spz} \cdot \mathrm{mL}^{-1}$. However, this concentration fluctuates slightly over time, and in between different experiments. This variation is explained by the dilution of gametes from a concentrated environment to the feed tank, and the difficulty in maintaining a fresh spermatozoa suspension in this tank which provides the UF membrane. The average membrane inlet concentration is $25,399 \mathrm{spz} \cdot \mathrm{mL}^{-1}$, including respective minimum and maximum values of 11,360 and $41,675 \mathrm{spz} \cdot \mathrm{mL}^{-1}$ for a filtration duration of 30 minutes and $7,432 \mathrm{spz} . \mathrm{mL}^{-1}$ for a filtration time of 60 minutes including respective minimum and maximum values of 1,305 and $19,318 \mathrm{spz} \cdot \mathrm{mL}^{-1}$. It's noted that in the case of the filtration time of 30 minutes, the retention capacities of the ultrafiltration process against an effluent four times more concentrated than in real conditions was evaluated. In these conditions, the concentration of spermatozoa obtained in the permeate was always below the detectability threshold of the flow cytometry analysis $\left(350 \mathrm{spz} \cdot \mathrm{mL}^{-1}\right)$. From the concentration factor in the membrane during the filtration cycle, it is possible to calculate the removal which varies on average between 2 and 4 $\log$ between the beginning and the end of the dead end filtration cycle for the experiment with the higher concentration. These decreases are significant and testify to the effectiveness of the treatment. As expected, the concentrations obtained in conventional backwashes are higher than the membrane inlet concentrations. The volumic concentration factor during the filtration cycle 
is not quite identical to the concentration factor of spermatozoa. This result, consistent with the fact that irreversible resistance increases with time, is due to the fact that conventional backwashing does not eliminate all the fouling. These backwash waters are effluents that must be treated and the membrane process presents two advantages: (i) as expected the reduction of the volume of effluents to be treated, here a factor of 10 is reached without optimisation; (ii) the viability of the spermatozoa. Spermatozoa movies showed that while an average of $18 \%$ of the spermatozoa viewed before filtration are moving and only $7 \%$ are mobile in backwash waters. A low viability was observed before filtration due to the analytical method. In fact, a concentrated spermatozoa sample was put in thin layer and under light for microscopic observation leading to their alteration in a few seconds. However, for each experiment, a significant decrease of the viability was observed after filtration. The viability of the spermatozoa is therefore compromised by this method of treatment. Moreover, with a volume of water almost identical to $\mathrm{CB}$, it was expected to find a much higher concentration of gametes in $\mathrm{AB}$ water. Nonetheless, the concentrations were much lower, ranging from 1.15 to 7.3 depending on the operating conditions. Flow cytometry (Tables 2 and 3) clearly shows a strong degradation of the integrity of spermatozoa and this is confirmed by the imaging study where no moving spermatozoa could be observed.

\section{III.2.2 Accidental pollution}

The objective of these tests was to evaluate the effect of a high concentrated effluent in gametes, over a few hours. Unlike the previous tests, the gametes were not continuously injected into the pilot's feed tank but introduced at once 5 min after each backwash. Two tests under identical filtration conditions were performed. Permeability, shown in Figure 6, was followed over the 5 cycles of filtration for both tests. Spermatozoa concentrations, more than 10 (test 1) and 25 (test 2) times higher than in the effluent treated with the same conditions in the case of chronic 
pollution, result in a stronger fouling of the membranes. In fact, the increase of accumulation of this material on the surface of the membrane results in a drop of permeability on the first cycle around 300 and $350 \mathrm{~L} \cdot \mathrm{h}^{-1} \cdot \mathrm{m}^{-2} \cdot \mathrm{bar}^{-1}$ whereas it was $150 \mathrm{~L} \cdot \mathrm{h}^{-1} \cdot \mathrm{m}^{-2} \cdot \mathrm{bar}^{-1}$ for chronic pollution treatment tests. If the fouling is expected for the treatment of this accidental pollution, Figures 6 (a-b) show the effectiveness of the backwash with a previous air injection for the control of this fouling. The variations in concentrations are detailed in Table 1. The target membrane inlet concentration, around 20 times greater than for the chronic pollution treatment test, is not constant on the duration of a backwash cycle. Several measurements were then performed on each cycle. The difference of concentration between the two tests can be explained by the quantity introduced into the alimentation tank at each injection, which is greater in test 1 (1.4 $10^{10}$ spermatozoa) than test $2\left(2.910^{10}\right.$ spermatozoa). Whatever the operating conditions, the concentration measured in the permeate is always lower than the limit concentration measurable by flow cytometry. Calculated abatements are, as expected, higher and vary between 3 and more than $5 \mathrm{log}$. These results confirm the retention of oyster spermatozoa for different ultrafiltration concentration conditions. The concentrations in the backwash waters are higher than in the inlet membrane, without reaching the volume concentration factor expected for the same reasons as the previous tests. As shown for chronical pollution, spermatozoa are strongly degraded by the injection of air in the backwashing phases (Table 4). The total retention of spermatozoa under different conditions tested, but also a control of fouling mastered by the use of special backwashes, demonstrate the performance of ultrafiltration for the treatment of high concentration spermatozoa pollution. 


\section{III.3 Treatment of seawater effluents containing oyster oocytes}

\section{III.3.1 Chronic pollution}

The experiments were carried out for two filtration times of 30 and 60 minutes over a period of 30 hours. The evolution of the permeability over the 30 hours of tests under both conditions is presented Figure 4 (c-d) for a filtration time of 60 minutes. To evaluate the extent of fouling generated by oocytes, Figure 4 (c-d) represents the comparison of the evolution of the permeability of seawater filtration with and without oocytes for the same filtration conditions. As for spermatozoa, these demonstrate that the fouling remains moderate during the treatment of these effluents. Indeed, the permeability drop over the duration of the test is $200 \mathrm{~L} \cdot \mathrm{h}^{-1} \cdot \mathrm{m}^{-}$ ${ }^{2} \cdot \mathrm{bar}^{-1}$ for the filtration time of $60 \mathrm{~min}$. In the case of a filtration time of $30 \mathrm{~min}$, filtrations with and without oocytes have the same profiles of permeability evolution, versus time, because of a lower fouling. The cytograms obtained on a filtration cycle are presented in Tables 6 and 7 and the concentrations in Table 5, with an example of evolution of concentration versus time Figure 7. The concentrations at the inlet of membrane are close to target concentrations, between 10 and 55 oo. $\mathrm{mL}^{-1}$ with an average of 28 oo. $\mathrm{mL}^{-1}$ and between 45 and 150 oo.mL $\mathrm{m}^{-1}$ with an average of 82 oo. $\mathrm{mL}^{-1}$ for filtration times of 30 and 60 minutes respectively. These analyses highlight the absence of oocytes in the permeate under the two filtration conditions tested. For these tests, it was possible to conclude that these species are completely retained by ultrafiltration. The calculated abatement over a filtration cycle vary between 2.5 and 3.5 and between 2.5 and 4.4 for filtration times of 30 and 60 minutes respectively. The concentrations recovered in the backwash waters are higher than those measured at the membrane inlet. Previous air injection during backwash, to drain the membrane, was shown to have no effect on the number of oocytes recovered during backflush. However, the flow cytometry analyses reveal an impact of the air injection on the integrity of these species recovered in the backwash 
water. Imaging analysis (Figure 8) clearly show this degradation of oocyte structure in the case of backwash preceded by an air injection.

\section{III.3.2 Accidental pollution}

Two tests were carried out for the same operating conditions of filtration. The permeability monitoring over the $5 \mathrm{~h}$ of tests is presented Figure $6(\mathrm{c}-\mathrm{d})$. The permeability drop observed on the first cycle, 350 and $250 \mathrm{~L} \cdot \mathrm{h}^{-1} \cdot \mathrm{m}^{-2} \cdot \mathrm{bar}^{-1}$ respectively for the tests 1 and 2, compared to the test simulating a chronic pollution $\left(<100 \mathrm{~L} \cdot \mathrm{h}^{-1} \cdot \mathrm{m}^{-2} \cdot \mathrm{bar}^{-1}\right)$ reflect the impact of the gametes concentration on membrane fouling. The importance of backwash with or without a previous air injection is, as for spermatozoa, illustrated by these evolutions of fouling. The effect of air backwashes is more marked at high concentrations. Concentrations obtained at different points of the system for both tests are synthesized in Table 5 and cytograms on a cycle, in Table 8 . The absence of oocyte detected by flow cytometry in the permeate demonstrates the total retention of oocytes from oysters Crassostrea gigas by ultrafiltration even in the case of a highly concentrated effluent (a concentration four times superior than the one in the case of chronic pollution under the same filtration conditions). The calculated abatements are between 4.6 and 5.1 Logs. As in the first oocyte treatment tests, the flow cytometry analyses reveal an impact of membrane draining before backwash on the physical integrity of the oocytes since the degraded oocyte levels measured in the different samples are around $50 \%$. This percentage refers to the rate of oocytes analysed labelled with IP which reveals degraded cells in a sample. The difference between the results obtained in samples from the same origin is explained by the oocytes used in the tests that have different origins. Indeed, rate of degraded oocytes in samples is directly linked to the quality of gametes used during the tests and explains the difference of non-integrity rate in membrane inlet. The quality of gametes depends on the oysters from which they are extracted. This initial quality of gametes injected in the system also 
had an impact on their robustness face to cleaning procedures. Indeed, the quality impacts the non-integrity rate in membrane inlet but also in backwash waters. However, whatever the integrity rate of oocytes in membrane inlet, about half of oocytes detected in air-backwash is degraded.

\section{Conclusion}

The objective of developing a process for the treatment of effluent shellfish farms, that may contain tetraploid biological material, whose release into the environment is a risk for marine biodiversity, is achieved. The retention of the species to be eliminated from these effluents: spermatozoa and oocytes form oyster Crassostrea gigas, was evaluated and the resistance of the process facing seawater with variable quality, containing or not gametes, was followed. The absence of gametes was found in the permeate samples analysed by flow cytometry and this result was validated whatever the pollution and their concentration. Abatements of 5 logs have thus been obtained. In terms of hydraulic performance, the addition of gametes to seawater has shown a moderate or significant impact on the fouling of membranes in the case of chronical or accidental pollutions respectively. However, the elimination of this fouling by backwash has proved effective. This is particularly the case of backwashes preceded by a step of membrane draining, which have a major role in controlling the drop of filtration performance. These specific backwashes thus allow effective cleaning of the membranes using a volume close to conventional backwashing. This is important information for the sustainability of the process in terms of yield. Without optimization, the volume of effluent is thus reduced by a minimum of 10 by ultrafiltration. The robustness of the process was tested over the 7 months of tests. Whether for the filtration of seawater under more or less "mild" conditions, or for the treatment of gamete containing effluents, the chemical cleanings carried out at the end of these tests have proved to be effective for maintaining stable permeability, proving the flexibility of the membranes facing effluents likely to be treated in a shellfish farm. Accidental and sudden 
degradation of the water quality to be treated was an opportunity to validate the membrane regeneration capacity after a very large fouling. A protection of the marine environment is obtained with ultrafiltration. A previous membrane draining showed that the use of air before backwashing also had an impact on the integrity of spermatozoa and oocytes. This impact of $\mathrm{AB}$ on these species is significant information for the industrial development of this process (Cordier et al., 2018). Following these results, fertilization tests with backwashing water will be performed to quantify the viability of gametes and will be the subject of forthcoming paper.

\section{ACKNOWLEDGEMENT}

The project leading to this publication has received funding from FEAMP (R FEA 4700 16FA $1000001)$.

\section{References}

Arimoto, M., Sato, J., Maruyama, K., Mimura, G., Furusawa, I., 1996. Effect of chemical and physical treatments on the inactivation of striped jack nervous necrosis virus (SJNNV). Aquaculture 143, 15-22. https://doi.org/10.1016/0044-8486(96)01261-6

Bamber, R.N., Seaby, R., Fleming, J.M., Taylor, C., 1994. Effects of entrainment passage on embryonic development of the pacific oyster Crassostrea gigas 33, 353-357.

Benabdelmouna, Ledu, 2008. Production of bivalve tetraploid molluscs from diploid parents. Patent 2146569 B1.

Bonisławska, M., Nędzarek, A., Drost, A., Rybczyk, A., Tórz, A., 2016. The application of ceramic membranes for treating effluent water from closed-circuit fish farming. Archives of Environmental Protection 42. https://doi.org/10.1515/aep-2016-0012

Brown, C., Russo, D., 1979. Ultraviolet-Light Disinfection of Shellfish Hatchery Sea-Water .1. Elimination of 5 Pathogenic Bacteria. Aquaculture 17, 17-23. https://doi.org/10.1016/0044-8486(79)90134-0

Castaing, J.B., Massé, A., Séchet, V., Sabiri, N.-E., Pontié, M., Haure, J., Jaouen, P., 2011. Immersed hollow fibres microfiltration $(\mathrm{MF})$ for removing undesirable micro-algae and protecting semi-closed aquaculture basins. Desalination 276, 386-396. https://doi.org/10.1016/j.desal.2011.03.081

Chen, S., Yu, J., Wang, H., Yu, H., Quan, X., 2015. A pilot-scale coupling catalytic ozonationmembrane filtration system for recirculating aquaculture wastewater treatment. Desalination 363, 37-43. https://doi.org/10.1016/j.desal.2014.09.006

Cobcroft, J.M., Battaglene, S.C., 2013. Ultraviolet irradiation is an effective alternative to ozonation as a sea water treatment to prevent Kudoa neurophila (Myxozoa: 
Myxosporea) infection of striped trumpeter, Latris lineata (Forster). Journal of Fish Diseases 36, 57-65. https://doi.org/10.1111/j.1365-2761.2012.01413.x

Cordier, C., Stavrakakis, C., Sauvade, P., Coelho, F., Moulin, P., 2018. Treatment of effluents from oyster farm by membrane process.

Delacroix, S., Vogelsang, C., Tobiesen, A., Liltved, H., 2013. Disinfection by-products and ecotoxicity of ballast water after oxidative treatment - Results and experiences from seven years of full-scale testing of ballast water management systems. Marine Pollution Bulletin 73, 24-36. https://doi.org/10.1016/j.marpolbul.2013.06.014

Field, R.W., Pearce, G.K., 2011. Critical, sustainable and threshold fluxes for membrane filtration with water industry applications. Advances in Colloid and Interface Science 164, 38-44. https://doi.org/10.1016/j.cis.2010.12.008

Frerichs, G.N., Tweedie, A., Starkey, W.G., Richards, R.H., 2000. Temperature, pH and electrolyte sensitivity, and heat, UV and disinfectant inactivation of sea bass žDicentrarchus labrax/ neuropathy nodavirus 12 .

Gemende, B., Gerbeth, A., Pausch, N., von Bresinsky, A., 2008. Tests for the application of membrane technology in a new method for intensive aquaculture. Desalination 224, 5763. https://doi.org/10.1016/j.desal.2007.04.080

Guilbaud, J., Wyart, Y., Moulin, P., 2015. Microfiltration and ultrafiltration of Mediterranean seawater at semi-industrial scale: membrane comparison and sustainable conditions of filtration, Euromembrane 2015, September 6-10, RWTH University, Aachen, Allemagne.

Guilbaud, Wyart, Klaag, Moulin, 2018. Comparison of seawater and freshwater ultrafiltration on semi-industrial scale: ballast water treatment application. Journal of Membrane Science and Research.

Gullian, M., Espinosa-Faller, F.J., Nunez, A., Lopez-Barahona, N., 2012. Effect of turbidity on the ultraviolet disinfection performance in recirculating aquaculture systems with low water exchange. Aquaculture Research 43, 595-606. https://doi.org/10.1111/j.13652109.2011.02866.x

Guo, X., DeBrosse, G., Allen, S., 1996. All-triploid Pacific oysters (Crassostrea gigas Thunberg) produced by mating tetraploids and diploids. Aquaculture 142, 149-161. https://doi.org/10.1016/0044-8486(95)01243-5

Harvianto, G., 2013. Removal Organic Contaminants on Aquaculture Using Ultrafiltration Membranes. Indonesian Scholars Journal.

Heeb, M.B., Criquet, J., Zimmermann-Steffens, S.G., von Gunten, U., 2014. Oxidative treatment of bromide-containing waters: Formation of bromine and its reactions with inorganic and organic compounds - A critical review. Water Research 48, 15-42. https://doi.org/10.1016/j.watres.2013.08.030

IMO, 2009. Harmful aquatic organism in ballast water. International Maritime Organization.

Jegatheesan, V., Senaratne, N., Steicke, C., Kim, S.-H., 2009. Powdered activated carbon for fouling reduction of a membrane in a pilot-scale recirculating aquaculture system. Desalination and Water Treatment 5, 1-5.

Kasai, H., Kawana, K., Labaiden, M., Namba, K., Yoshimizu, M., 2011. Elimination of Escherichia coli from oysters using electrolyzed seawater. Aquaculture 319, 315-318. https://doi.org/10.1016/j.aquaculture.2011.07.025

Kasai, H., Yoshimizu, M., Ezura, Y., 2002. Disinfection of Water for Aquaculture. Fisheries science 68, 821-824. https://doi.org/10.2331/fishsci.68.sup1_821

Kornmueller, A., 2007. Review of fundamentals and specific aspects of oxidation technologies in marine waters. Water Science and Technology 55, 1-6. https://doi.org/10.2166/wst.2007.379 
Lazarova, V., Savoye, P., Janex, M., Blatchley, E., Pommepuy, M., 1999. Advanced wastewater disinfection technologies: State of the art and perspectives. Water Science and Technology 40, 203-213. https://doi.org/10.1016/S0273-1223(99)00502-8

Le Goic, N., Hegaret, H., Boulais, M., Beguel, J.-P., Lambert, C., Fabioux, C., Soudant, P., 2014. Flow Cytometric Assessment of Morphology, Viability, and Production of Reactive Oxygen Species of Crassostrea gigas Oocytes. Application to Toxic Dinoflagellate (Alexandrium minutum) Exposure. Cytometry Part A 85A, 1049-1056. https://doi.org/10.1002/cyto.a.22577

Li, Q., Osada, M., Kashihara, M., Hirohashi, K., Kijima, A., 2000. Effects of ultraviolet irradiation on genetical inactivation and morphological features of sperm of the Pacific oyster Crassostrea gigas. Fisheries Science 66, 91-96. https://doi.org/10.1046/j.14442906.2000.00013.x

Liltved, H., Hektoen, H., Efraimsen, H., 1995. Inactivation of bacterial and viral fish pathogens by ozonation or UV irradiation in water of different salinity. Aquacultural Engineering 14, 107-122. https://doi.org/10.1016/0144-8609(94)P4430-J

Muchmore, D., Epel, D., 1973. The effects of chlorination of wastewater on fertilization in some marine invertebrates. Marine Biology 19, 93-95. https://doi.org/10.1007/BF00353579

Nora'aini, A., Wahab Mohammad, A., Jusoh, A., Hasan, M.R., Ghazali, N., Kamaruzaman, K., 2005. Treatment of aquaculture wastewater using ultra-low pressure asymmetric polyethersulfone (PES) membrane. Desalination 185, 317-326. https://doi.org/10.1016/j.desal.2005.03.084

Pulefou, T., Jegatheesan, V., Steicke, C., Kim, S.-H., 2008. Application of submerged membrane bioreactor for aquaculture effluent reuse. Desalination 221, 534-542. https://doi.org/10.1016/j.desal.2007.01.114

Qin, G., Liu, C., Richman, N., Moncur, J., 2005. Aquaculture wastewater treatment and reuse by wind-driven reverse osmosis membrane technology: a pilot study on Coconut Island, Hawaii. Aquacultural Engineering 36 365-378. https://doi.org/10.1016/j.aquaeng.2004.09.002

Qualls, R., Johnson, J., 1983. Bioassay and Dose Measurement In UV Disinfection. Applied and Environmental Microbiology 45, 872-877.

Reiser, S., Wuertz, S., Schroeder, J.P., Kloas, W., Hanel, R., 2011. Risks of seawater ozonation in recirculation aquaculture - Effects of oxidative stress on animal welfare of juvenile turbot (Psetta maxima, L.). Aquatic Toxicology 105, 508-517. https://doi.org/10.1016/j.aquatox.2011.08.004

Sharrer, M.J., Summerfelt, S.T., 2007. Ozonation followed by ultraviolet irradiation provides effective bacteria inactivation in a freshwater recirculating system. Aquacultural Engineering 37, 180-191. https://doi.org/10.1016/j.aquaeng.2007.05.001

Sharrer, M.J., Summerfelt, S.T., Bullock, G.L., Gleason, L.E., Taeuber, J., 2005. Inactivation of bacteria using ultraviolet irradiation in a recirculating salmonid culture system. Aquacultural Engineering 33, 135-149. https://doi.org/10.1016/j.aquaeng.2004.12.001

Stavrakakis, C., Papin, M., Dupuy, B., Riou, K., Penisson, C., Nourry, M., Hatt, P.-J., Buchet, V., Palvadeau, H., 2017. Désinfection de l'eau de mer - DESIMER Etude des sousproduits de désinfection. LSPC - Ifremer.

Summerfelt, S.T., 2003. Ozonation and UV irradiation. Aquac. Eng 28, 36.

Szmukala, M., Szaniawska, D., 2009. Application of ceramic membranes in water treatment for fish hatchery supplying purposes. Desalination 240, 117-126. https://doi.org/10.1016/j.desal.2007.12.038 
Torgersen, Y., Hastein, T., 1995. Disinfection In Aquaculture. Revue Scientifique Et Technique De L'Office International Des Epizooties 14, 419-434. https://doi.org/10.20506/rst.14.2.845

Vignier, J., Volety, A.K., Rolton, A., Le Goic, N., Chu, F.-L.E., Robert, R., Soudant, P., 2017. Sensitivity of eastern oyster (Crassostrea virginica) spermatozoa and oocytes to dispersed oil: Cellular responses and impacts on fertilization and embryogenesis. Environmental Pollution 225, 270-282. https://doi.org/10.1016/j.envpol.2016.11.052

Wold, P.-A., Holan, A.B., Oie, G., Attramadal, K., Bakke, I., Vadstein, O., Leiknes, T.O., 2014. Effects of membrane filtration on bacterial number and microbial diversity in marine recirculating aquaculture system (RAS) for Atlantic cod (Gadus morhua L.) production. Aquaculture 422, 69-77. https://doi.org/10.1016/j.aquaculture.2013.11.019

Yang, L., Zhou, H., Moccia, R., 2006. Membrane filtration coupled with chemical precipitation to treat recirculating aquaculture system effluents. Journal of Environmental Quality 35, 2419-2424. https://doi.org/10.2134/jeq2005.0480 


\section{Figure and table captions}

Figure 1: Evolution of fouling resistances versus time a: $\left[\mathrm{J}=60 \mathrm{~L} \cdot \mathrm{h}^{-1} \cdot \mathrm{m}^{-2} ; \mathrm{t}_{\text {filtration }}=20 \mathrm{~min}\right]$ and b: $\left[\mathrm{J}=80 \mathrm{~L} \cdot \mathrm{h}^{-1} \cdot \mathrm{m}^{-2} ; \mathrm{t}_{\text {filtration }}=45 \mathrm{~min}\right]$

Figure 2: Evolution of permeability versus time

a: $\left[\mathrm{J}=60 \mathrm{~L} \cdot \mathrm{h}^{-1} \cdot \mathrm{m}^{-2} ; \mathrm{t}_{\text {filtration }}=30 \mathrm{~min}\right]$

b: $\left[\mathrm{J}=60 \mathrm{~L} \cdot \mathrm{h}^{-1} \cdot \mathrm{m}^{-2} ; \mathrm{t}_{\text {filtration }}=60 \mathrm{~min}\right]$

Figure 3: Membrane regeneration over the test period and after an accidental degradation of seawater quality

Figure 4: Evolution of permeability versus time $\left[\mathrm{J}=60 \mathrm{~L} \cdot \mathrm{h}^{-1} \cdot \mathrm{m}^{-2} ; \mathrm{t}_{\text {filtration }}=60 \mathrm{~min}\right]$

a-c: treatment of chronic pollution of gametes - b-d: comparison with seawater filtration

Figure 5: Evolution of spermatozoa concentration versus time [Chronic pollution; J $=60{\mathrm{~L} . \mathrm{h}^{-}}^{-}$ $\left.{ }^{1} \cdot \mathrm{m}^{-2} ; \mathrm{t}_{\text {filtration }}=30 \mathrm{~min}\right]$

Figure 6: Evolution of permeability during 5 hours for the treatment of spermatozoa (a-b) or oocytes (c-d) $\left[\mathrm{J}=60 \mathrm{~L} \cdot \mathrm{h}^{-1} \cdot \mathrm{m}^{-2}\right.$ and $\mathrm{t}_{\text {filtration }}=60 \mathrm{~min}$; Accidental pollution $]-\mathrm{a}-\mathrm{c}$. Test 1 and bd. Test 2

Figure 7: Evolution of oocytes concentration versus time [Chronic pollution; $\mathrm{J}=60 \mathrm{~L} \cdot \mathrm{h}^{-1} \cdot \mathrm{m}^{-2}$; $\left.\mathrm{t}_{\text {filtration }}=60 \mathrm{~min}\right]$

Figure 8: Pictures of oocytes before filtration and in backwash water

Figure 1 

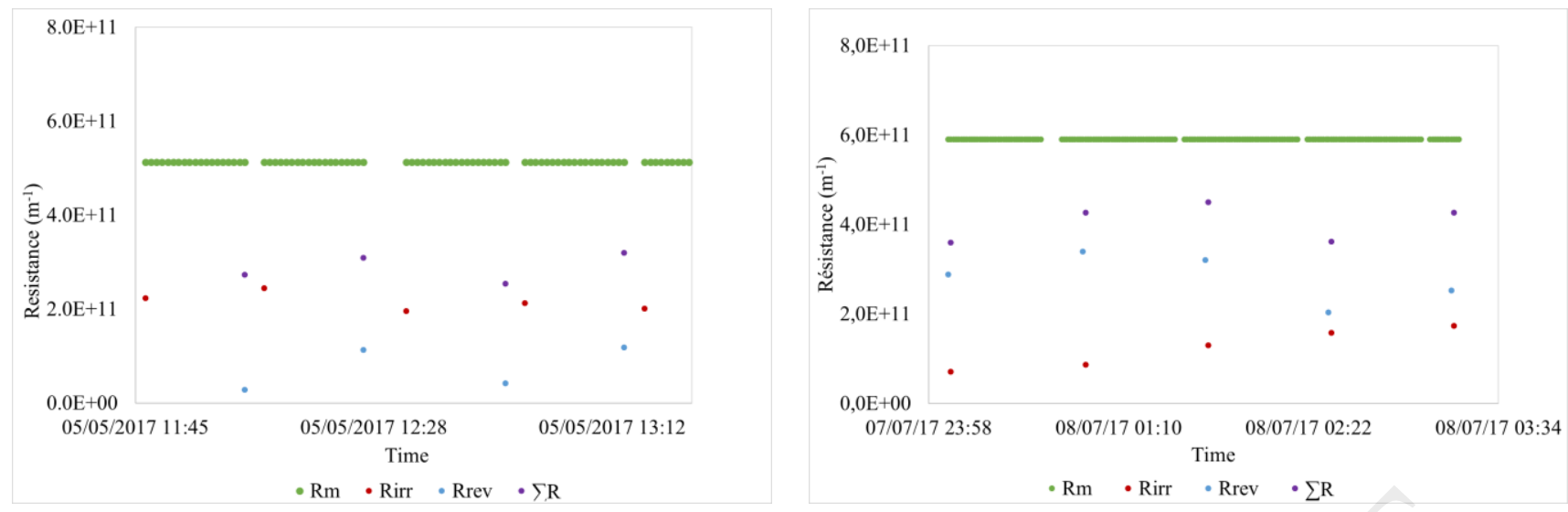

(a)

(b) 


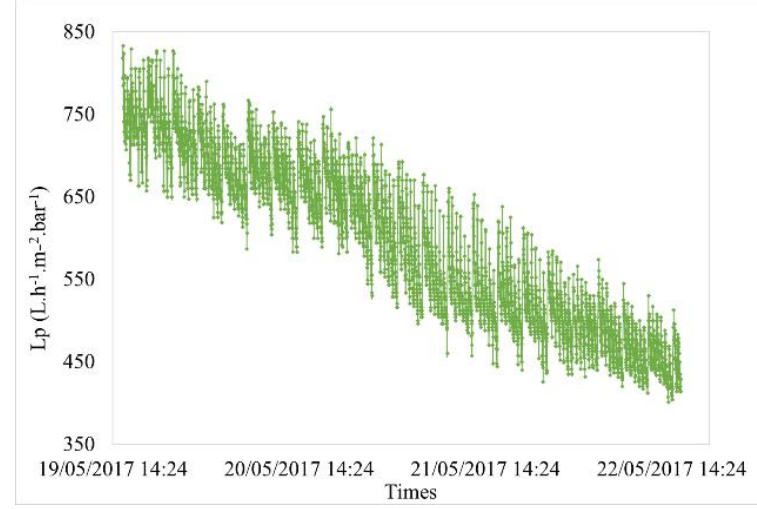

(a)

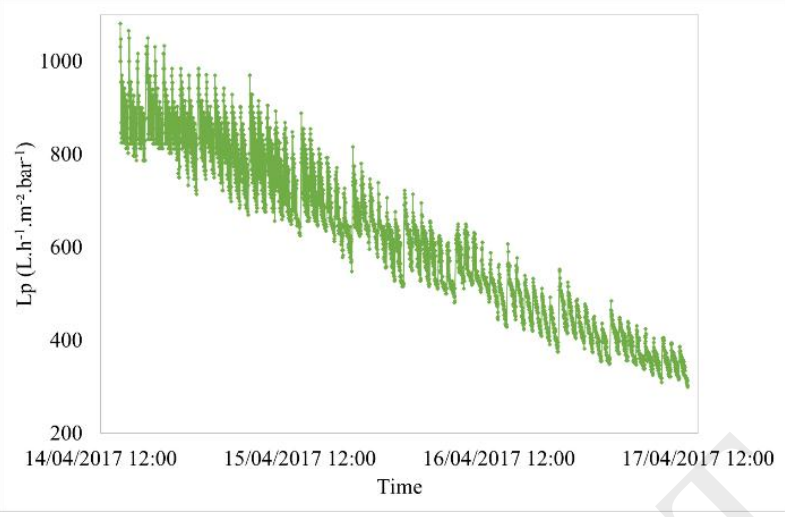

(b)

Figure 2 


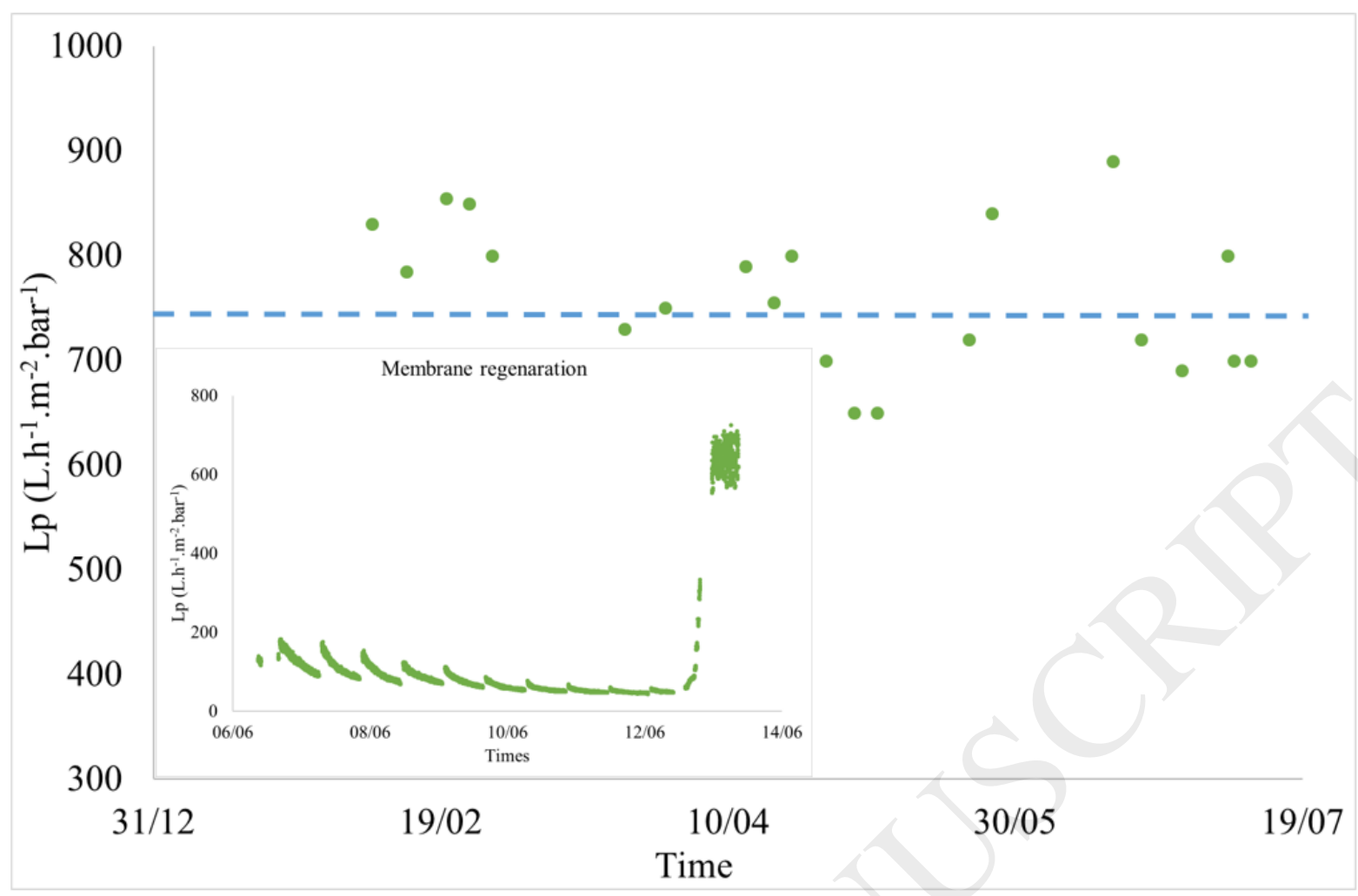

Figure 3 

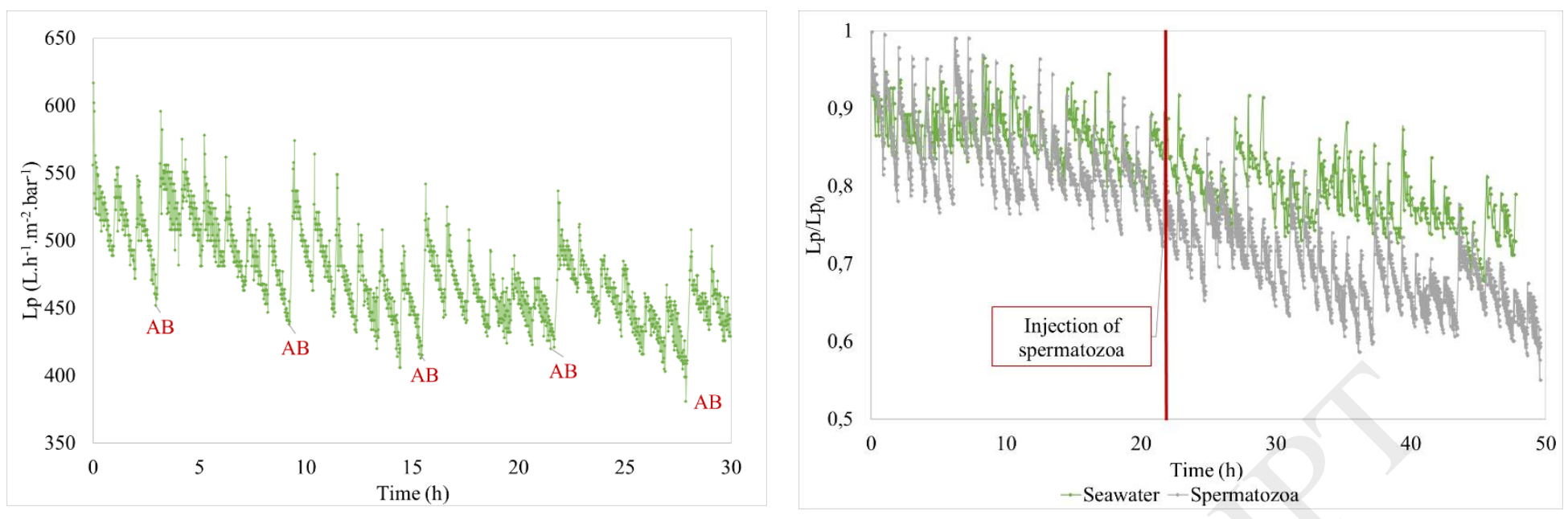

(a)

(b)
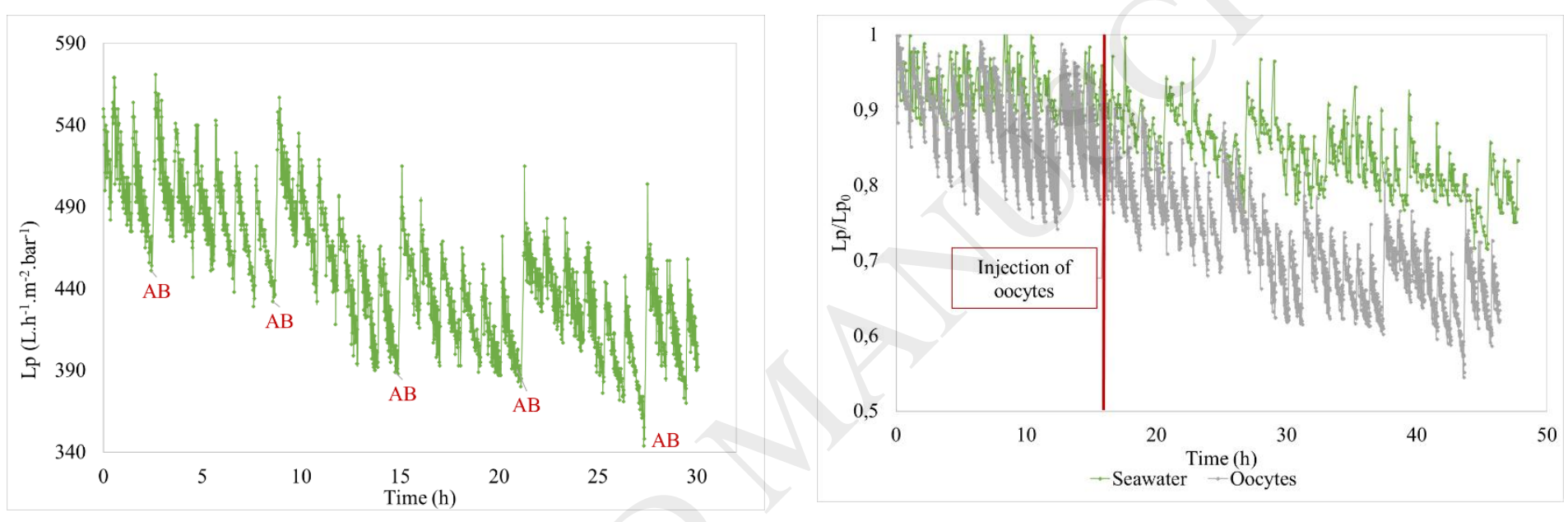

(c)

(d)

Figure 4 


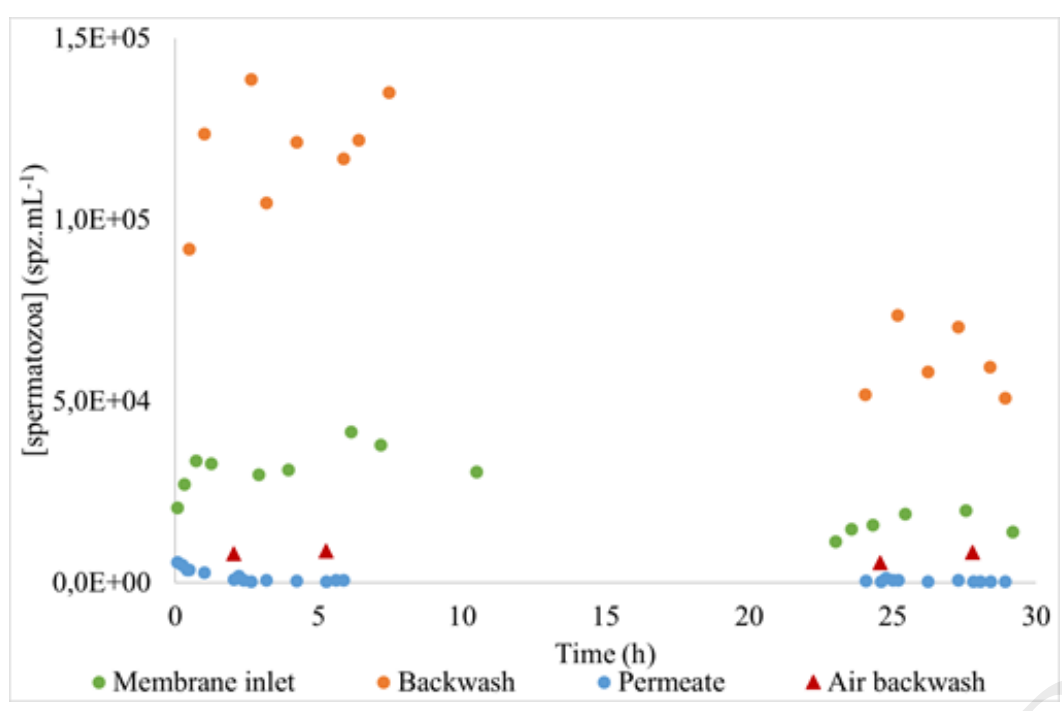

Figure 5 
(a)

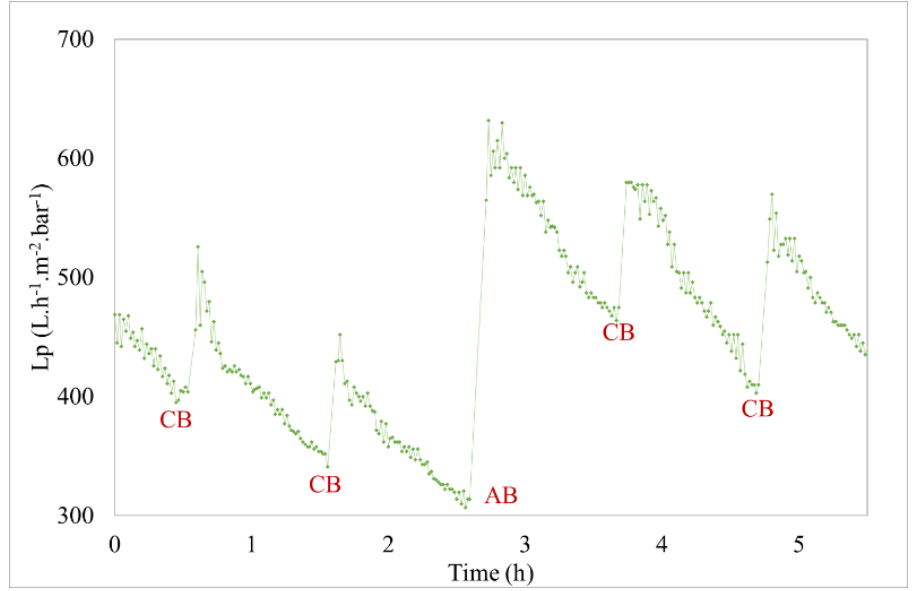

(c)

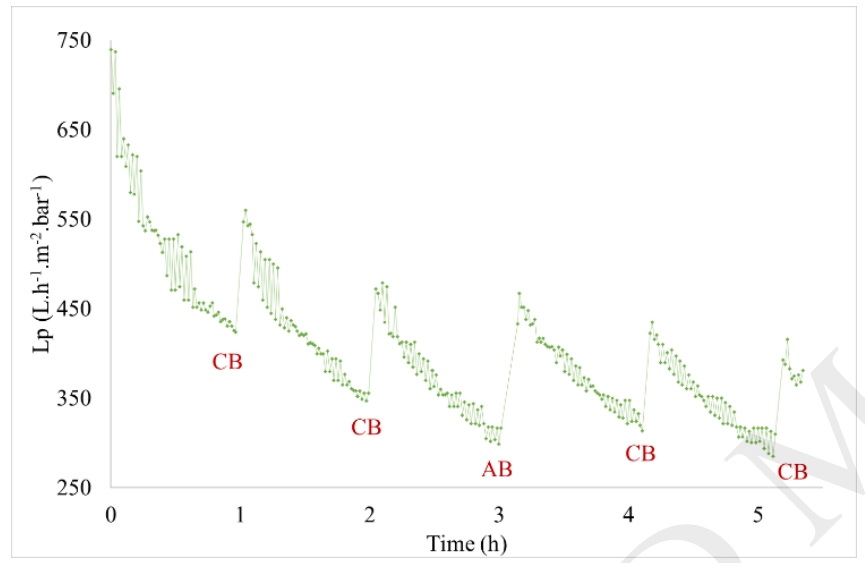

(c) (b)

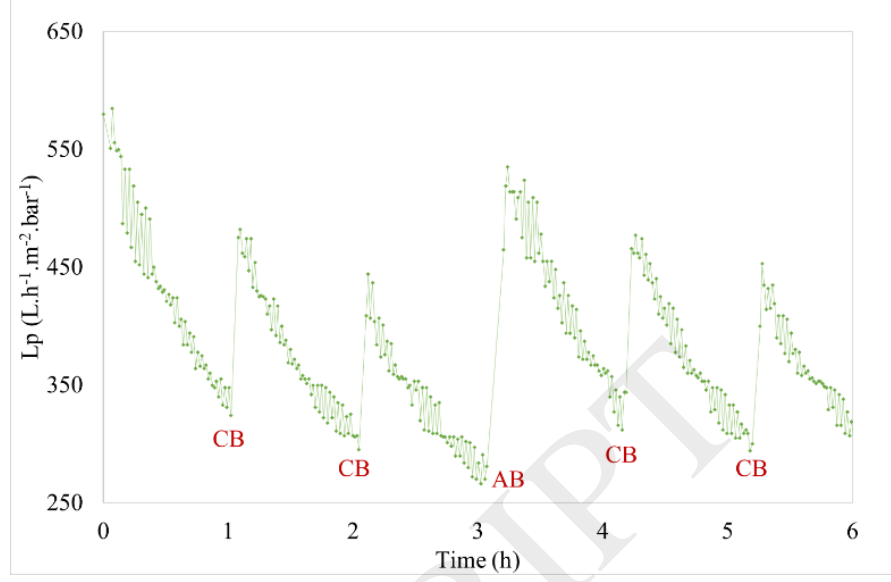

(d)

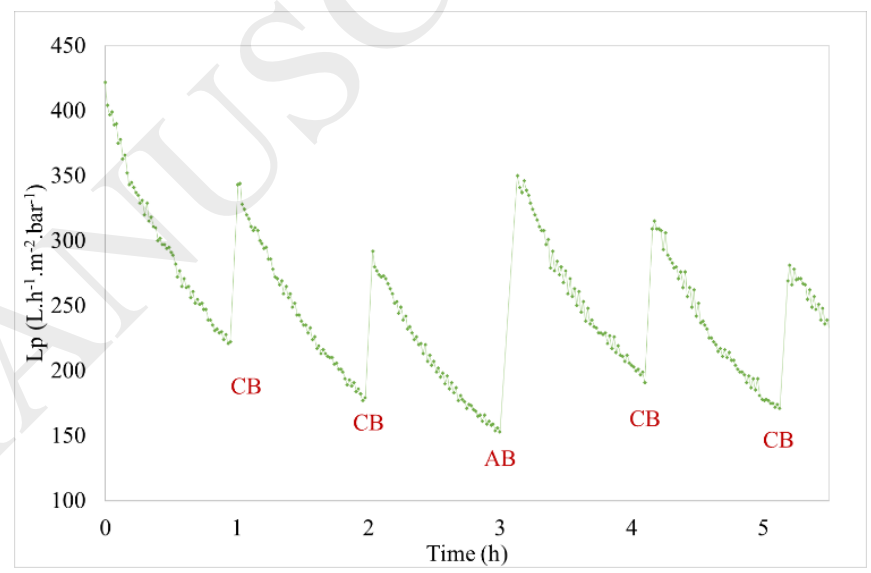

(d)

Figure 6 


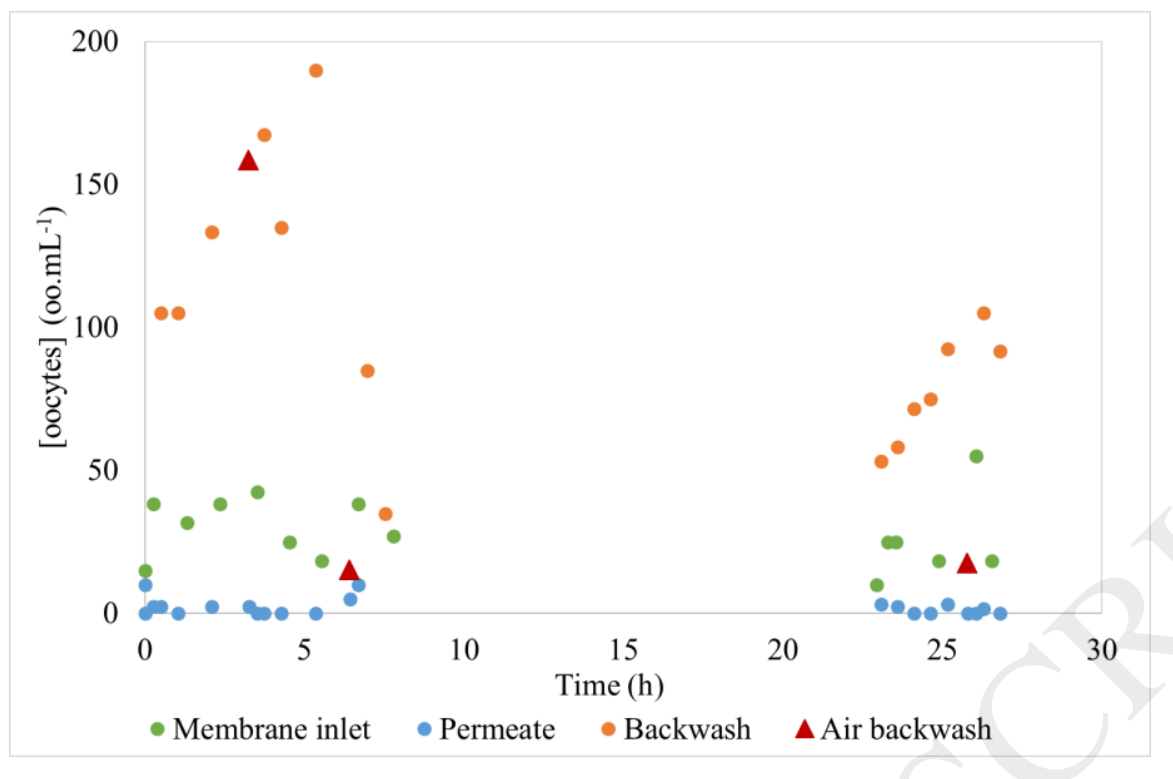

Figure 7 


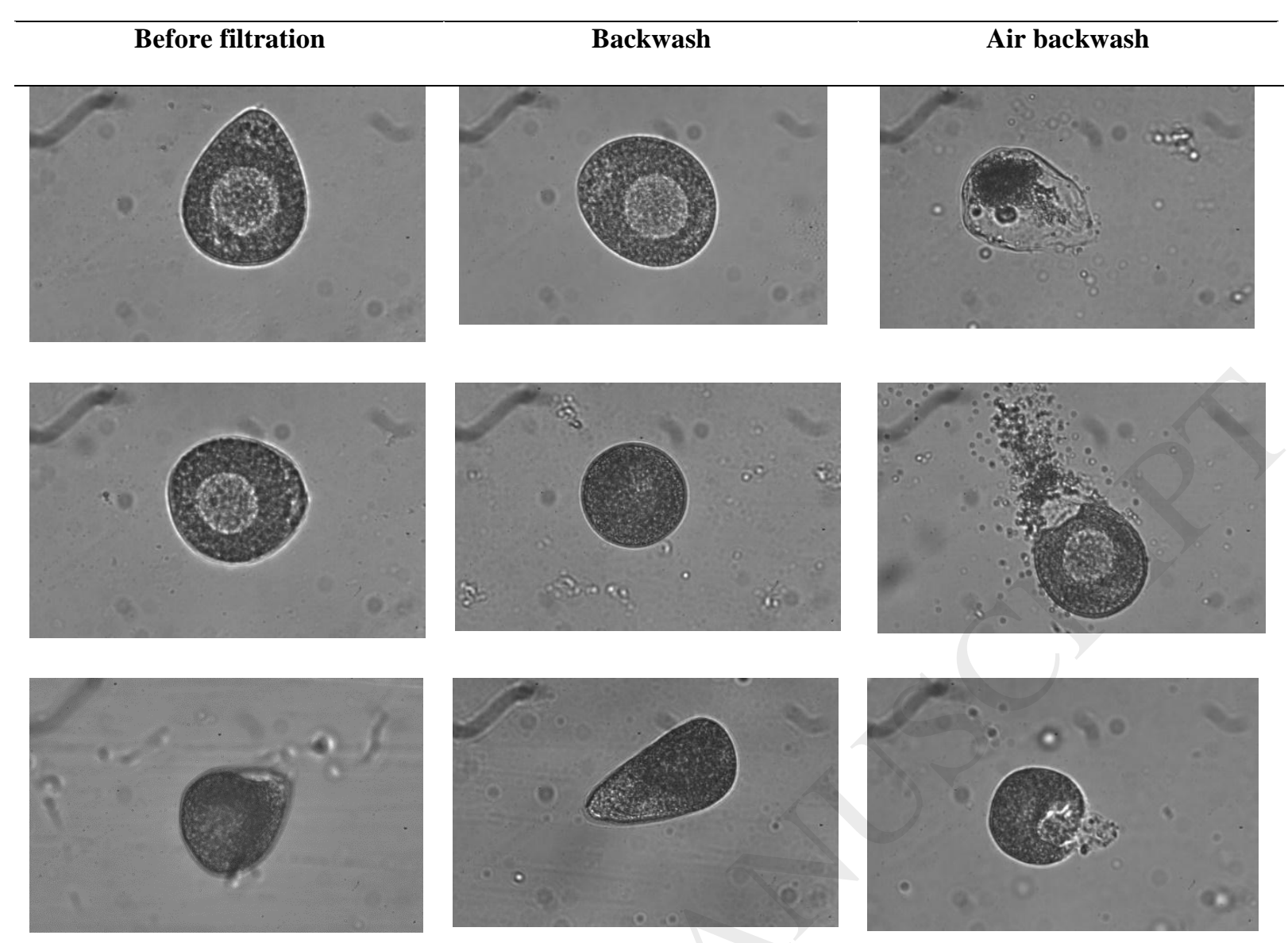

Figure 8 
Table 1: Spermatozoa concentrations (minimum, maximum and average) for the different conditions of treatment at different points of the system and removal obtained

Table 2: Flow cytometry analysis of spermatozoa $-\left[\mathrm{J}=60 \mathrm{~L} \cdot \mathrm{h}^{-1} \cdot \mathrm{m}^{-2}\right.$ and $\mathrm{t} \mathrm{t}_{\text {filtration }}=30 \mathrm{~min}$; Chronic pollution]

Table 3: Flow cytometry analysis of spermatozoa $-\left[\mathrm{J}=60 \mathrm{~L} \cdot \mathrm{h}^{-1} \cdot \mathrm{m}^{-2}\right.$ and $\mathrm{t}_{\text {filtration }}=60 \mathrm{~min}$; Chronic pollution]

Table 4: Flow cytometry analysis of spermatozoa $-\left[\mathrm{J}=60 \mathrm{~L} \cdot \mathrm{h}^{-1} \cdot \mathrm{m}^{-2}\right.$ and $\mathrm{t}_{\text {filtration }}=60 \mathrm{~min}$; Accidental pollution] for 2 feed concentrations

Table 5: Oocytes concentrations (minimum, maximum and average) for the different conditions of treatment at different points of the system and removal obtained

Table 6: Flow cytometry analysis of oocytes $-\left[\mathrm{J}=60 \mathrm{~L} \cdot \mathrm{h}^{-1} \cdot \mathrm{m}^{-2}\right.$ and $\mathrm{t}_{\text {filtration }}=30 \mathrm{~min}$; Chronic pollution]

Table 7: Flow cytometry analysis of oocytes $-\left[\mathrm{J}=60 \mathrm{~L} \cdot \mathrm{h}^{-1} \cdot \mathrm{m}^{-2}\right.$ and $\mathrm{t}_{\text {filtration }}=60 \mathrm{~min}$; Chronic pollution]

Table 8: Flow cytometry analysis of oocytes $-\left[\mathrm{J}=60 \mathrm{~L} \cdot \mathrm{h}^{-1} \cdot \mathrm{m}^{-2}\right.$ and $\mathrm{t}_{\text {filtration }}=60 \mathrm{~min}$; Accidental pollution] for 2 feed concentrations 
Table 1

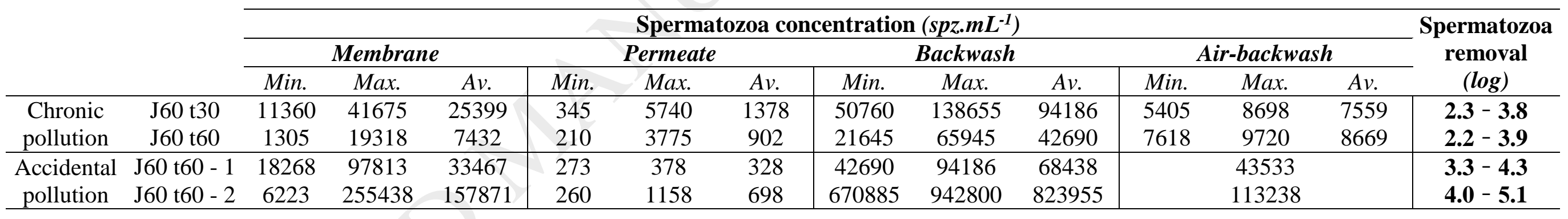


Table 2
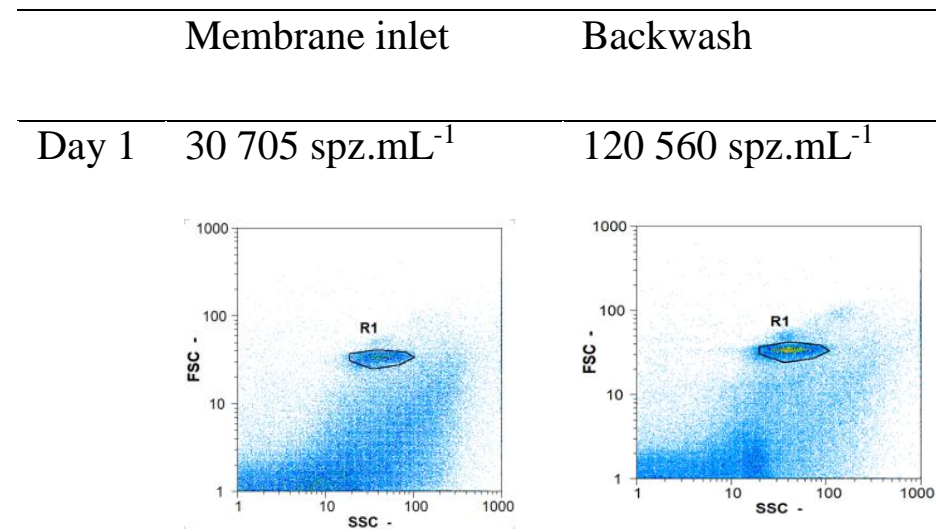

Air backwash

Permeate

Day 218305 spz.mL ${ }^{-1}$

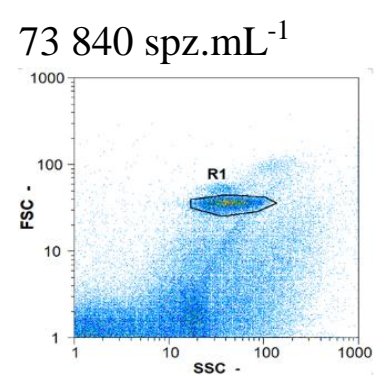

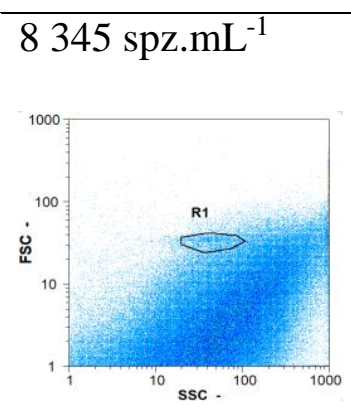

10170 spz.mL $L^{-1}$

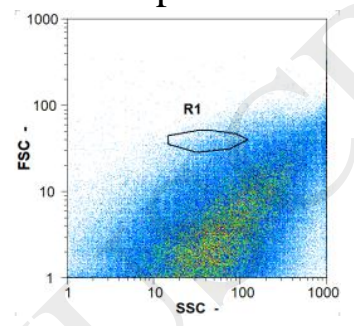

415 spz.mL $\mathrm{m}^{-1}$

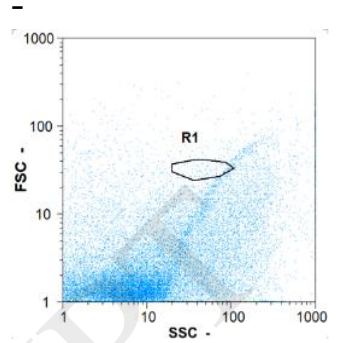

545 spz.mL ${ }^{-1}$

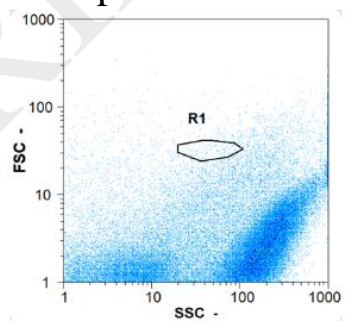

\section{Print in colour}


Table 3

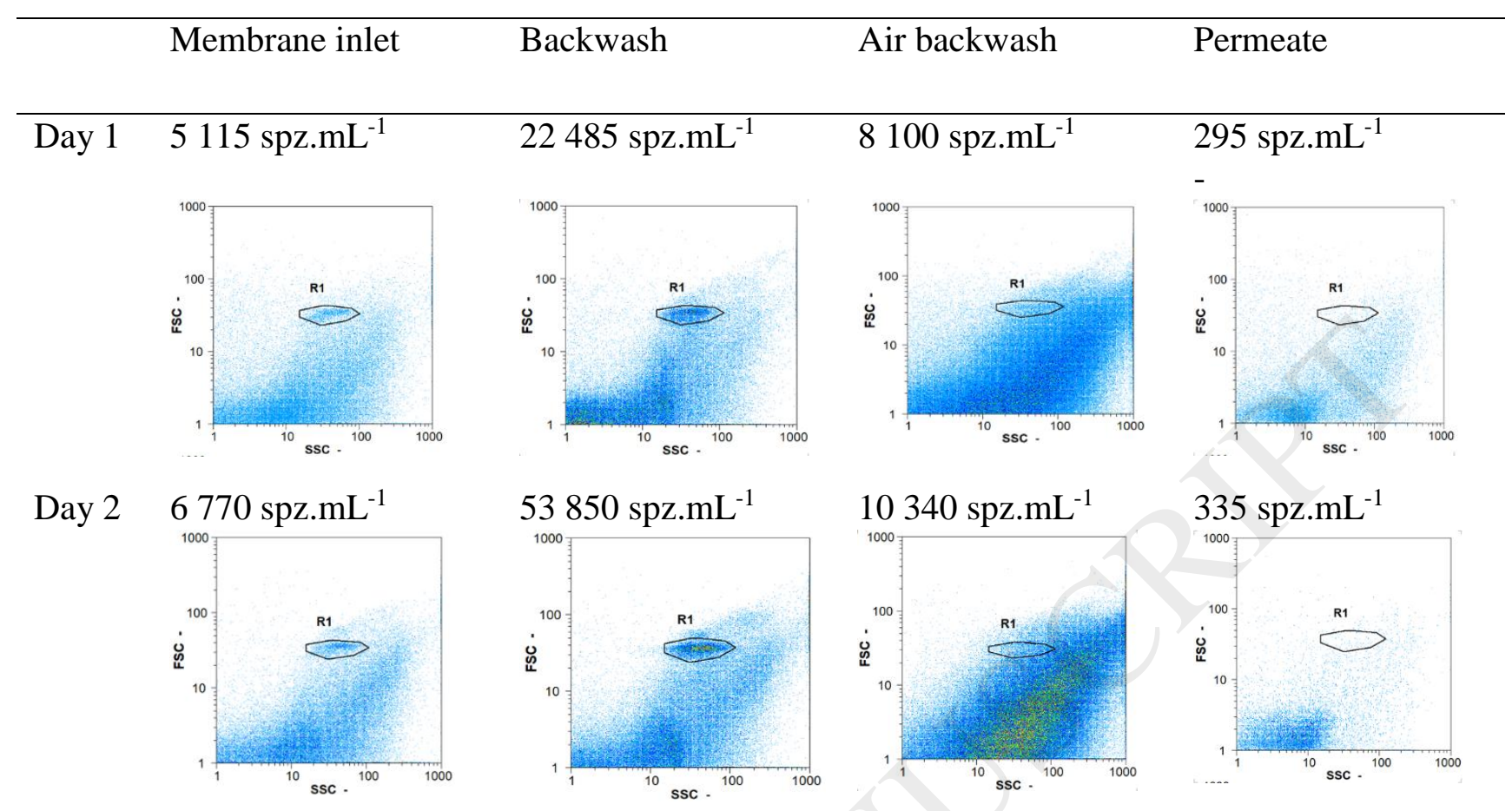

Print in colour 
Table 4

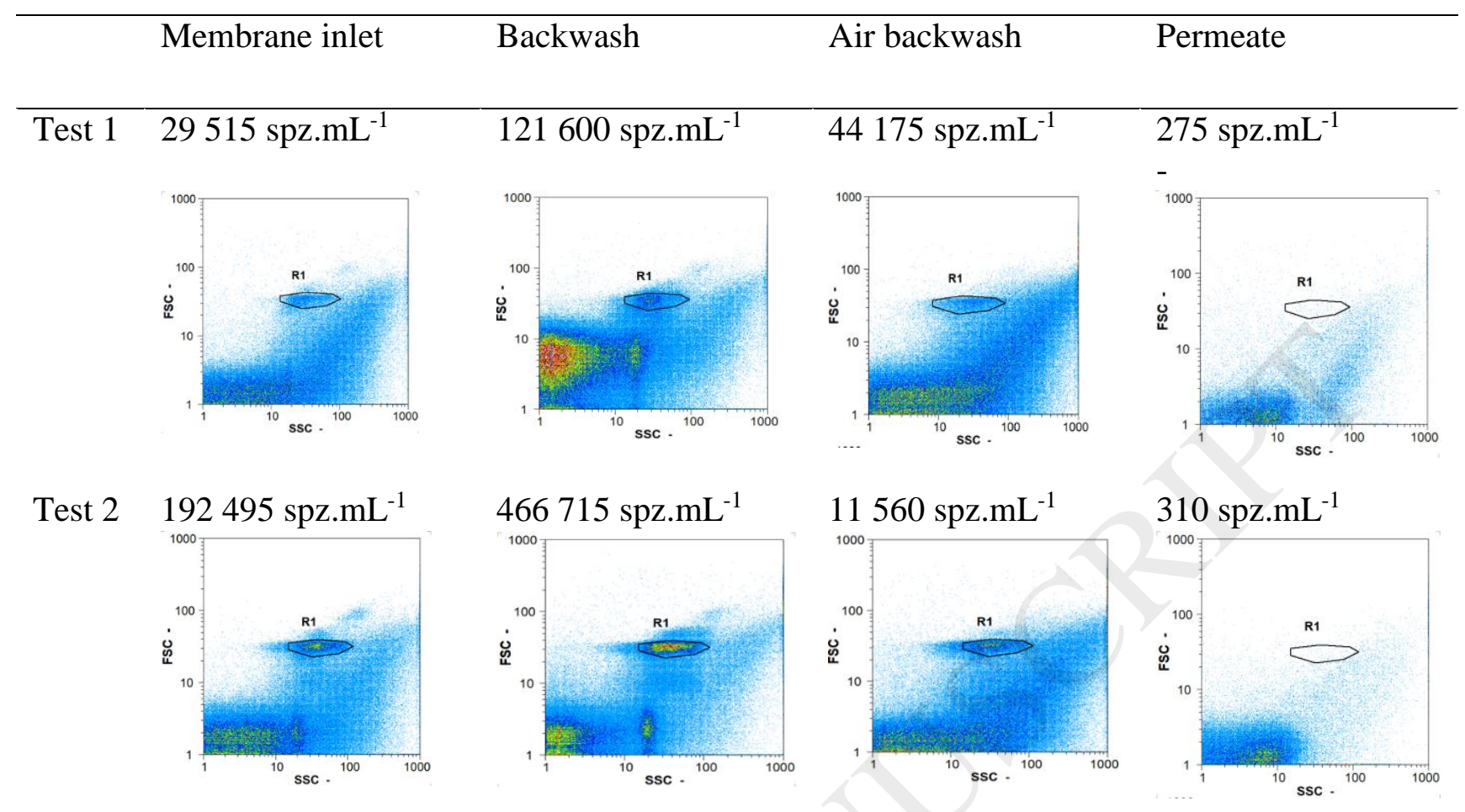

\section{Print in colour}


Table 5

Oocytes concentration $\left(o o . m L^{-1}\right)$

\begin{tabular}{|c|c|c|c|c|c|c|c|c|c|c|c|c|c|c|}
\hline & \multicolumn{12}{|c|}{ Oocytes concentration $\left(o o . m L^{-1}\right)$} & \multirow{3}{*}{$\begin{array}{c}\text { Oocytes } \\
\text { removal } \\
(\log )\end{array}$} \\
\hline & & \multicolumn{3}{|c|}{ Membrane } & \multicolumn{3}{|c|}{ Permeate } & \multicolumn{3}{|c|}{ Backwash } & \multicolumn{3}{|c|}{ Air-backwash } & \\
\hline & & Min. & Max. & $A v$. & Min. & Max. & $A v$. & Min. & Max. & $A v$. & Min. & Max. & $A v$. & \\
\hline Chronic & $\mathrm{J} 60 \mathrm{t} 30$ & 10 & 55 & 28 & 0 & 3 & 1 & 35 & 190 & 100 & 15 & 158 & 64 & $2.5-3.5$ \\
\hline pollution & J60 t60 & 45 & 150 & 82 & 0 & 20 & 6 & 215 & 758 & 491 & 402 & 505 & 453 & $2.5-4.4$ \\
\hline Accidental & J60 t60 - 1 & 5 & 440 & 214 & 0 & 0 & 0 & 1033 & 1433 & 1255 & & 573 & & $3.5-4.6$ \\
\hline pollution & J60 t60 - 2 & 95 & 950 & 378 & 0 & 3 & 0 & 1505 & 2093 & 1932 & & 1655 & & $4.0-5.1$ \\
\hline
\end{tabular}


Table 6

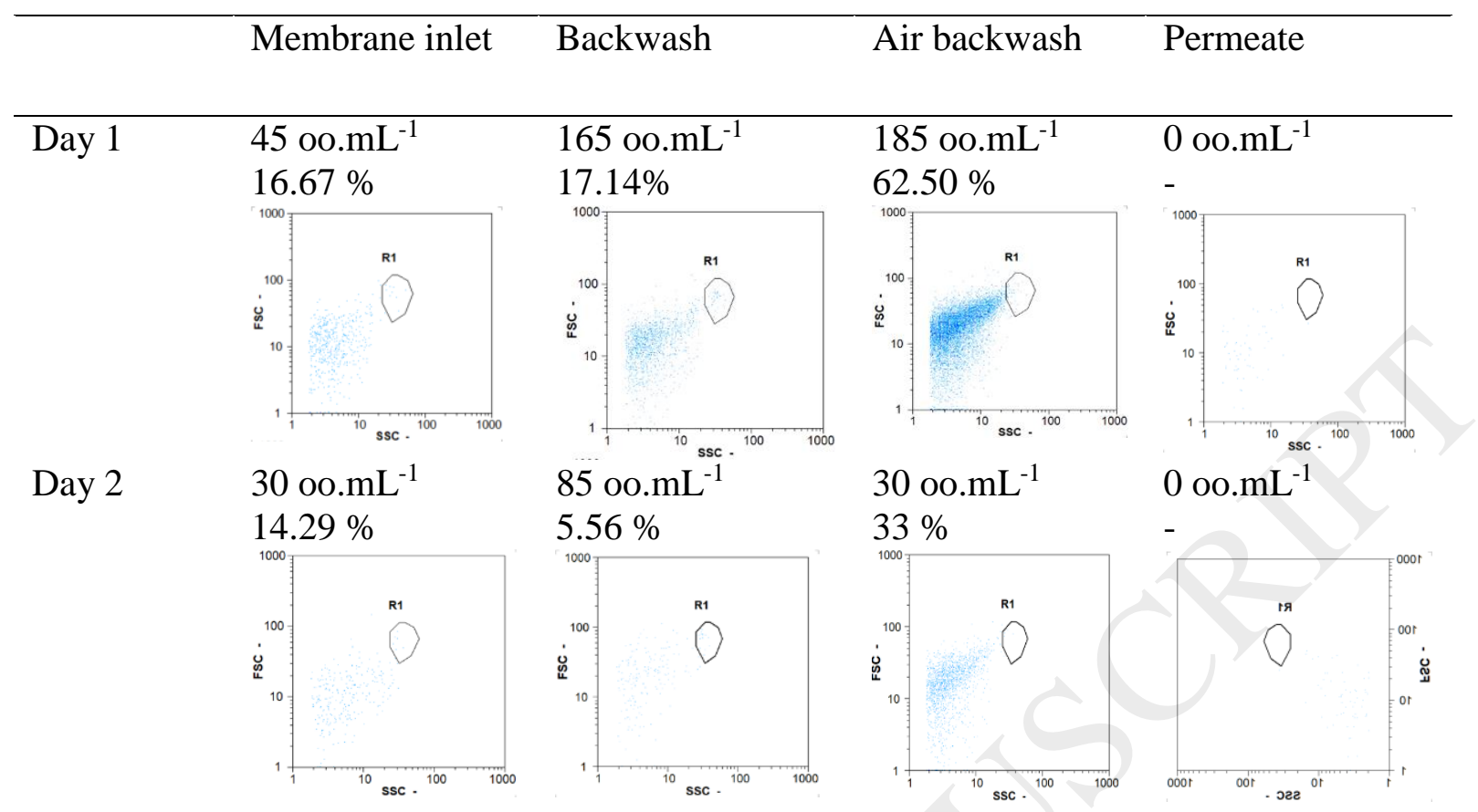

Print in colour 


\section{Table 7}

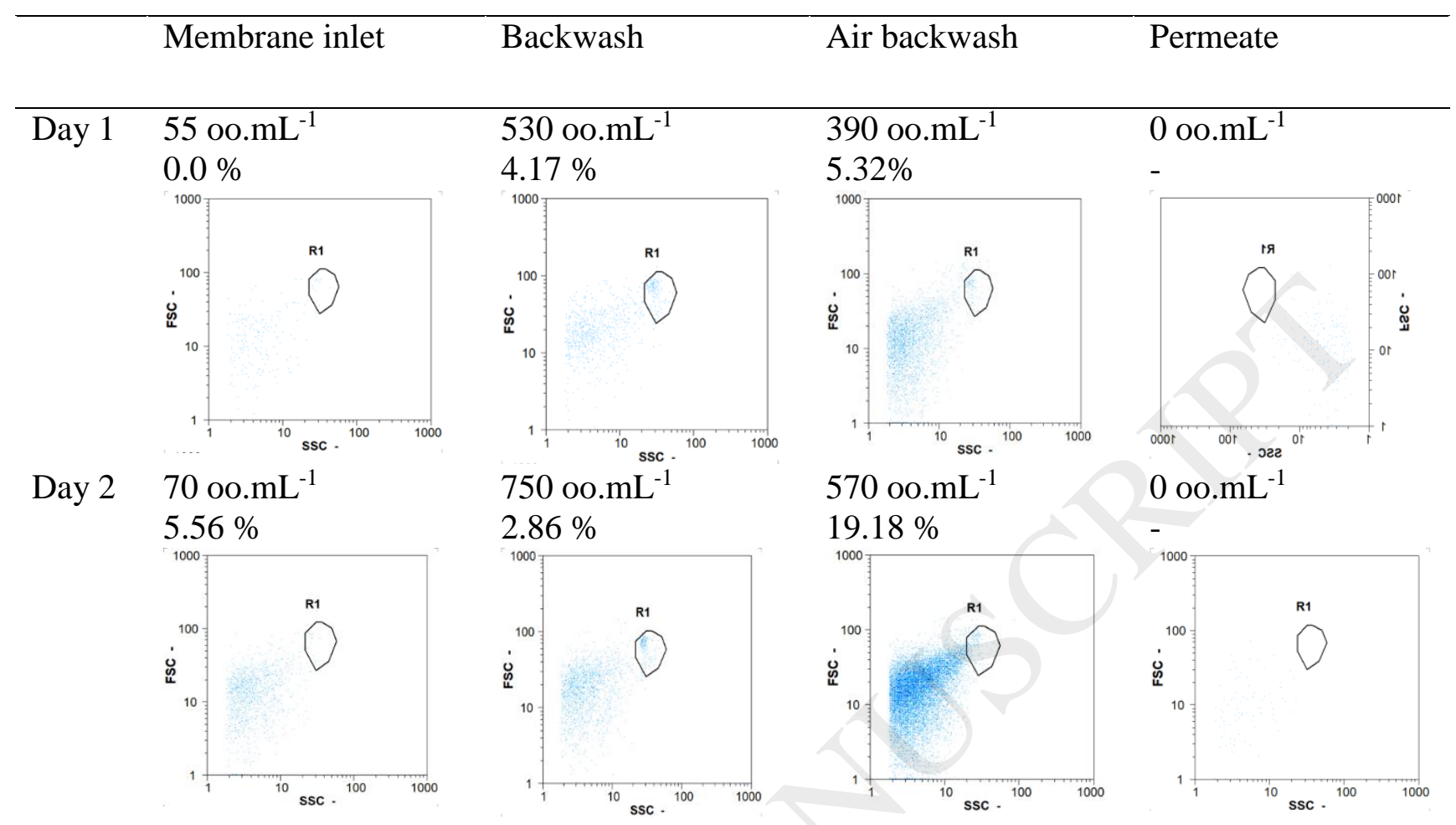

Print in colour 
Table 8

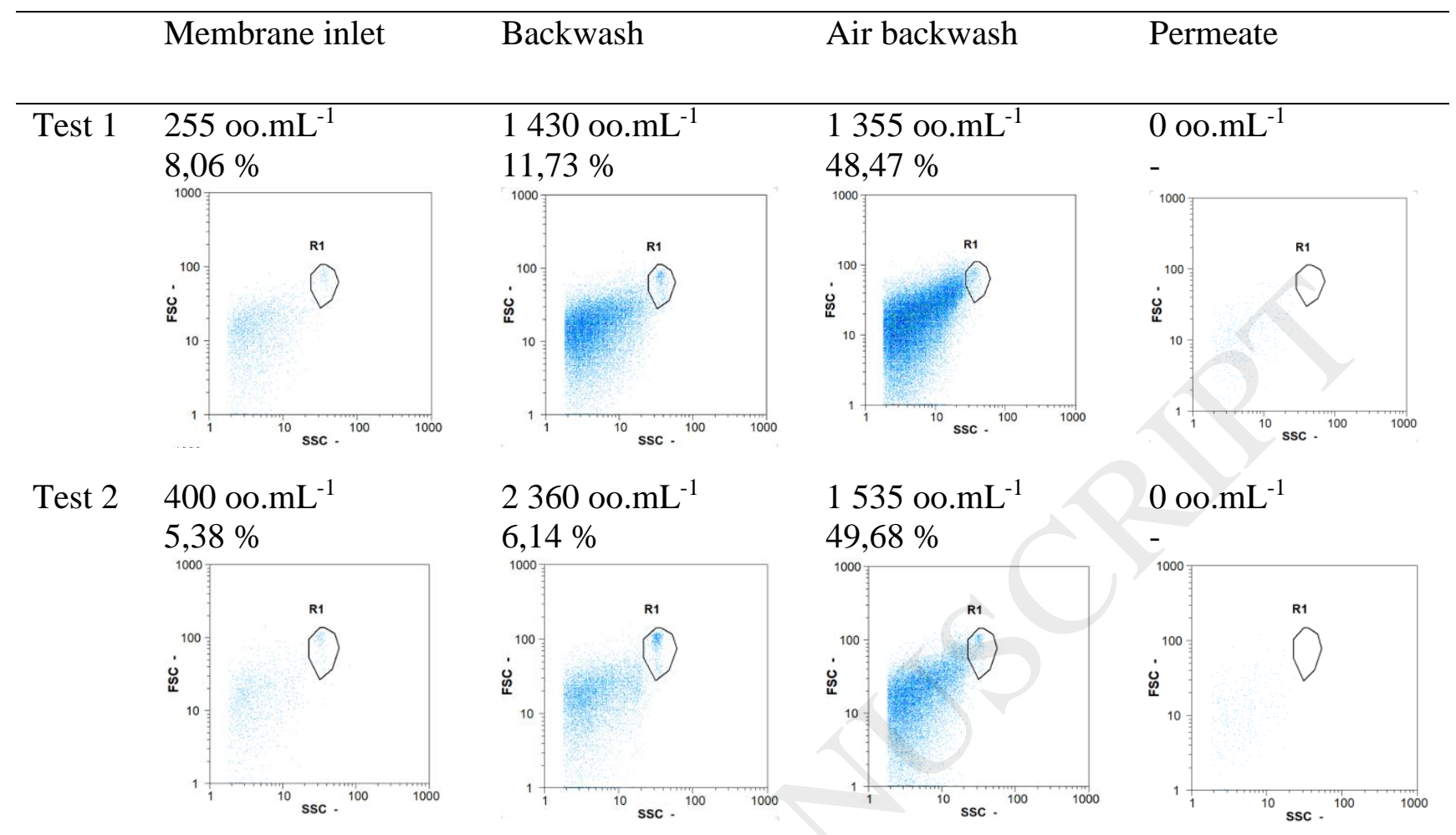

\section{Print in colour}

